File 2629 ja-1 (13)

Bangladesh J. Sci. Ind. Res. 42(1), 89-96, 2007

\title{
Efficacy in-vivo of Different Fungicides in Controlling Stemphylium Blight of Lentil During 1998-2001
}

\author{
M. Ihsanul Huq ${ }^{\mathrm{a}}$ and A. Z. M. Nowsher Ali Khan ${ }^{\mathrm{b}}$

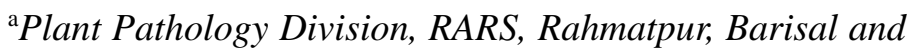 \\ ${ }^{\mathrm{b}}$ Department of Botany, Dhaka University, Dhaka-1000, Bangladesh
}

\begin{abstract}
In an experiment with seven different fungicides such as Rovral 50WP @ $0.2 \%$, Dithane M-45 @ 0.2 \%, Tilt 250EC @ 0.05 \%, Cupravit @ 0.3 \%, Macuprax @ $0.25 \%$, Ridomil MZ-72 @ $0.2 \%$ and Bavistin 50WP @ $0.15 \%$ were tested in the field during 1998-2001 to control Stemphylium blight lentil. Among the fungicides Rovral 50WP@ $0.2 \%$ was noted as the most effective fungicide followed by Dithane M-45@ $0.2 \%$ and Tilt 250EC @ $0.05 \%$.
\end{abstract}

\section{Introduction}

Lentil (Lens culinaris Medik.) is the second most important pulse crop in terms of both area and production and rates the highest consumers' preference. It contributes $25 \%$ of the total pulse production (Anonymous, 1991). Lentil is a popular and widely cultivated crop in Bangladesh and in many other tropical countries. In Bangladesh at least 17 diseases attack the crop causing appreciable yield losses. Among them blight (Stemphylium botryosum), rust (Uromyces fabae L.) and foot and root rot (Sclerotium rolfsii Sacc.) are considered as major problems for lentil cultivation in the country (Ahmed, 1985). Occurrence of Stemphylium blight is the most common and destructive disease in all lentil growing areas of Bangladesh. Though the occurrence of the disease has been recorded in the country long ago.
Its adverse effect on lentil yield was experimentally demonstrated (Bakr and Zahid, 1986). Stemphylium botry-osum was isolated from blighted infected leaf samples of lentil (Chowdhury and Asheque, 1996). Control of plant diseases becomes most successful and economical when management approach involving several methods are employed including chemical means, cultural practices and use of resistant host etc.

Time of sowing had marked effect upon the level of disease incidence and thus by manipulating the sowing time incidence might be avoided (Hedge and Anahosur, 1994). Some agronomical practices viz., intercropping, mixed cropping and sole cropping have effect in influencing micro-climate and forming physical barrier in crop field to prevent some organisms responsible for various 
diseases. This is a non-chemical way to check and retard the spread of disease. Cropping system is a very effective means to check the spread of disease (Gour and Singh, 1996).

\section{Materials and Methods}

The experiment was conducted under natural epiphytotic condition. The experiment was laid out in a piece of land following RCB design with three replications (Zaman, et. al., 1982). The unit plot size was $4 \mathrm{~m} \times 3 \mathrm{~m}$ with $25 \mathrm{~cm}$ row to row spacing. A susceptible genotype L-81124 was sown on November 23. Seven fungicides and one control comprised eight treatments. The fungicides included were Rovral 50WP @ 0.2 \%, Dithane M-45@0.2\%, Bavistin 50WP@ $0.15 \%$, Cupravit @0.3\%, Tilt 250EC @ 0.05 \%, Macuprax @0.25\% and Ridomil MZ-72@0.2\%. Concentration of fungicides and their active ingredients are presented in Table I.

The experiment was kept under constant observation. First spray was given just after the appearance of disease symptom in the field. Four sprays were given at an interval of 15 days. Data were recorded before every spray using 1-9 scoring scale from 25 randomly tagged plants/plot. Percent Disease Index (PDI) was computed according to the formula as described below (Wheeler, 1969) and calculated based on the final data recorded at 15 days after the last spray.

$$
\begin{array}{r}
\text { PDI }=\frac{\text { Sum of numerical values }}{\text { No. of plant parts observed }} \\
\quad \times \frac{100}{\text { Maximum disease rating }}
\end{array}
$$

Percent data were statistically analyzed after arcsine transformation Percent Disease Control (PDC) was calculated on the basis of the following formula (Shivankar and Wangikar, 1993).

$$
\begin{aligned}
& \text { PDC }= \frac{\text { Disease in control plot }-}{\text { Disease in control plot }} \\
& \text { Disease in treated plot } \\
& \text { X }
\end{aligned}
$$

Data were recorded on yield and yield attributes after necessary sun drying. Yield

Table I. Selected fungicides, concentration used and their active ingredients

\begin{tabular}{l|c|l}
\hline \multicolumn{1}{c|}{ Fungicides } & Concentration (\%) & \multicolumn{1}{c}{ Active ingredients } \\
\hline 1. Rovral 50WP & 0.2 & Iprodione $50 \%$ \\
2. Dithane M-45 & 0.2 & Mancozeb $80 \%+$ manganese ethylene \\
3. Bavistin 50WP & 0.15 & $50 \%$ Methyl 2 benzimidazole carbamate \\
4. Cupravit & 0.3 & Copper oxychloride with 50\% metallic copper \\
5. Tilt 250EC & 0.05 & Propiconazol 250g a.i./litre \\
6. Macuprax & 0.25 & 580g natural bordeaux mixture and 70g cufraneb $/ \mathrm{kg}$ \\
7. Ridomil MZ-72 & 0.2 & Metalaxyl 80g a.i. $/ \mathrm{kg}+$ mancozeb 640g a.i./kg. \\
\hline
\end{tabular}


increase over the control was calculated. All data were analyzed statistically and means were compared by DMRT (Steele and Torrie, 1980). The correlation among percent yield increased over control and percent disease control was calculated.

\section{Results and Discussion}

The results of in-vivo efficacy of different fungicides in controlling Stemphylium blight of lentil during 1998-2001are presented in Table viz., 2, 3 and 4. Data on Percent Disease Index, Percent Disease Control, 1000-seed weight, yield/plant (g), yield/plot (kg), yield/ha (kg) and percent yield increase over control were noted.

It is indicated in Table II that during 19981999 all fungicides had effect over the control in reducing the disease. Among the fungicides tested Rovral 50WP @ 0.2 \% was found most effective followed by Dithane M45 @ 0.2 \% and Tilt 250EC @ $0.05 \%$ and differed significantly from the other fungicides tested.

Rovral 50WP showed the highest PDC (52.3) followed by Dithane M-45 (51.2).

In respect of yield/ha and other yield attributes viz., 1000-seed weight, yield/plant and yield/plot. Rovral 50WP exhibited the best performance with $79.2 \%$ yield increase over control and PDC (52.4) followed by Dithane M-45. The yield (79.2 kg/ha) obtained by Rovral 50WP was found statistically the highest among the treatments and differed from others. Rovral 50WP @ 0.2 \% was

Table II. In-vivo effect of fungicides on disease severity and yield of lentil during 1998-1999

\begin{tabular}{l|c|c|c|c|c|c|c}
\hline Treatment & PDI & PDC & $\begin{array}{c}1000-\text { seed } \\
\text { wt. (g) }\end{array}$ & $\begin{array}{c}\text { Yield/ } \\
\text { plant (g) }\end{array}$ & $\begin{array}{c}\text { Yield/ } \\
\text { plot (kg) }\end{array}$ & $\begin{array}{c}\text { Yield/ } \\
\text { (kg) }\end{array}$ & $\begin{array}{c}\% \text { Yield } \\
\text { increase }\end{array}$ \\
\hline Rovral 50WP & $40.2 \mathrm{~d}$ & 52.4 & $18.2 \mathrm{a}$ & $1.46 \mathrm{a}$ & $1.20 \mathrm{a}$ & $1000.0 \mathrm{a}$ & 79.2 \\
Dithane M-45 & $41.2 \mathrm{abc}$ & 51.2 & $15.9 \mathrm{~b}$ & $1.23 \mathrm{~b}$ & $0.97 \mathrm{~b}$ & $916.0 \mathrm{~b}$ & 64.2 \\
Bavistin 50WP & $76.0 \mathrm{ab}$ & 9.9 & $14.3 \mathrm{bc}$ & $1.00 \mathrm{c}$ & $0.77 \mathrm{c}$ & $641.7 \mathrm{bc}$ & 14.9 \\
Cupravit & $75.0 \mathrm{bc}$ & 11.1 & $14.8 \mathrm{bc}$ & $1.00 \mathrm{c}$ & $0.72 \mathrm{c}$ & $600.0 \mathrm{bc}$ & 7.4 \\
Tilt 250EC & $42.5 \mathrm{abc}$ & 49.6 & $15.4 \mathrm{~b}$ & $1.16 \mathrm{bc}$ & $0.98 \mathrm{~b}$ & $816.6 \mathrm{~b}$ & 46.2 \\
Macuprax & $72.6 \mathrm{c}$ & 13.9 & $14.9 \mathrm{bbc}$ & $1.10 \mathrm{bc}$ & $0.70 \mathrm{c}$ & $583.3 \mathrm{~cd}$ & 4.5 \\
Ridomil MZ-72 & $83.2 \mathrm{abc}$ & 1.4 & $14.9 \mathrm{~b}$ & $1.03 \mathrm{~d}$ & $0.68 \mathrm{c}$ & $566.0 \mathrm{~cd}$ & 1.4 \\
Control & $84.4 \mathrm{a}$ & - & $13.4 \mathrm{c}$ & $0.46 \mathrm{c}$ & $0.67 \mathrm{c}$ & $558.3 \mathrm{~cd}$ & - \\
\hline F-test & $* *$ & & $* *$ & $* *$ & $* *$ & $* *$ & \\
CV (\%) & 8.47 & & 4.59 & 7.05 & 8.44 & 1.38 & \\
\hline
\end{tabular}

Mean (s) in the column followed by common letter (s) do not differ significantly at 0.01 level. In case of PDI, analysis was done after arcsine transformation. 
found as the most effective fungicide to control Stemphylium blight of lentil.

It is revealed from Table III that during 19992000 all treatments had significant effect over control except Macuprax and Ridomil by Macuprax @ $0.25 \%$ (9.1). The highest yield (858.3kg) was obtained from Rovral 50WP@0.2\% followed by 791.6kg of Dithane M- 45 @0.2\%. Rovral 50WP contributed to $51.5 \%$ yield increase over the control and PDC (48.5).

Table III. In-vivo effect of fungicides on disease severity and yield of lentil during 1999-2000

\begin{tabular}{l|c|c|c|c|c|c|c}
\hline Treatment & PDI & PDC & $\begin{array}{c}1000 \text {-seed } \\
\text { wt. (g) }\end{array}$ & $\begin{array}{c}\text { Yield/plant } \\
(\mathrm{g})\end{array}$ & $\begin{array}{c}\text { Yield/plot } \\
(\mathrm{kg})\end{array}$ & $\begin{array}{c}\text { Yield/ha } \\
(\mathrm{kg})\end{array}$ & $\begin{array}{c}\% \text { Yield } \\
\text { increase }\end{array}$ \\
\hline Rovral 50 WP & $40.0 \mathrm{f}$ & 48.5 & $22.0 \mathrm{a}$ & $2.50 \mathrm{a}$ & $1.03 \mathrm{~b}$ & $858.3 \mathrm{a}$ & 51.5 \\
Dithane M-45 & $48.4 \mathrm{ef}$ & 37.6 & $19.8 \mathrm{ab}$ & $1.76 \mathrm{~b}$ & $0.95 \mathrm{c}$ & $791.6 \mathrm{~b}$ & 39.7 \\
Bavistin 50WP & $66.0 \mathrm{bc}$ & 14.9 & $19.0 \mathrm{abc}$ & $1.26 \mathrm{~d}$ & $0.85 \mathrm{cde}$ & $708.3 \mathrm{~d}$ & 25.0 \\
Cupravit & $67.4 \mathrm{~cd}$ & 13.1 & $18.0 \mathrm{bc}$ & $1.43 \mathrm{c}$ & $0.83 \mathrm{de}$ & $691.6 \mathrm{~d}$ & 22.6 \\
Tilt 250EC & $54.6 \mathrm{de}$ & 29.6 & $19.3 \mathrm{abc}$ & $1.43 \mathrm{c}$ & $0.91 \mathrm{~cd}$ & $758.3 \mathrm{c}$ & 33.8 \\
Macuprax & $70.4 \mathrm{abc}$ & 9.1 & $18.3 \mathrm{bc}$ & $1.16 \mathrm{~d}$ & $0.79 \mathrm{ef}$ & $658.3 \mathrm{e}$ & 16.2 \\
Ridomil-MZ-72 & $74.3 \mathrm{ab}$ & 4.3 & $16.8 \mathrm{bc}$ & $1.13 \mathrm{~d}$ & $0.70 \mathrm{f}$ & $583.3 \mathrm{f}$ & 2.9 \\
Control & $77.6 \mathrm{a}$ & - & $15.6 \mathrm{c}$ & $0.80 \mathrm{e}$ & $0.68 \mathrm{a}$ & $566.6 \mathrm{~g}$ & - \\
\hline F-test & $* *$ & & $* *$ & $* *$ & $* *$ & $* *$ & \\
CV (\%) & 4.2 & & 7.20 & 4.15 & 4.66 & 1.39 & \\
\hline
\end{tabular}

Mean (s) in the column followed by common letter (s) do not differ significantly at 0.01 level. In case of PDI, analysis was done after arcsine transformation.

MZ-72. Rovral 50WP@0.2 \% Reduced PDI significantly and performed the best followed by Dithane M-45 @ $0.2 \%$ and Tilt 250EC @ $0.05 \%$ showing PDI 40.0, 48.4 and 54.6, respectively.

In respect of PDC (Percent Disease Control), Rovral 50WP@ $0.2 \%$ had the best performance (48.4) followed by (37.6) of Dithane M45 @ $0.2 \%$. The lowest PDC was exhibited by Ridomil MZ-72@.0.2 \% (4.3) followed
It is evident from Table IV that during 20002001, the Percent Disease Index (PDI) was the lowest (34.2) in Rovral 50WP treated plot followed by 47.8 and 54.6 of Dithane M-45 and Tilt 250 EC treated plots, respectively.

The lowest control of disease was shown by Macuprax@0.25\%. All treatments had sig nificant effect over the control in respect of PDI. The highest PDC (54.0) and percent yield increase over control (106.9) was 
Table IV. In-vivo effect of fungicides on disease severity and yield of lentil during 2000-2001

\begin{tabular}{l|c|c|c|c|c|c|c}
\hline Treatment & PDI & PDC & $\begin{array}{c}1000 \text {-seed } \\
\text { wt. (g) }\end{array}$ & $\begin{array}{c}\text { Yield/plant } \\
(\mathrm{g})\end{array}$ & $\begin{array}{c}\text { Yield/plot } \\
(\mathrm{kg})\end{array}$ & $\begin{array}{c}\text { Yield/ha } \\
(\mathrm{kg})\end{array}$ & $\begin{array}{c}\text { \% Yield } \\
\text { increase }\end{array}$ \\
\hline Rovral 50WP & $34.2 \mathrm{e}$ & 54.0 & $22.3 \mathrm{a}$ & $2.20 \mathrm{a}$ & $1.20 \mathrm{a}$ & $1000.0 \mathrm{a}$ & 106.9 \\
Dithane M-45 & $47.8 \mathrm{de}$ & 35.8 & $20.3 \mathrm{ab}$ & $1.47 \mathrm{~cd}$ & $0.84 \mathrm{bc}$ & $704.0 \mathrm{~b}$ & 45.7 \\
Bavistin 50WP & $60.2 \mathrm{bc}$ & 19.2 & $18.3 \mathrm{bcd}$ & $1.56 \mathrm{~cd}$ & $0.67 \mathrm{dc}$ & $558.3 \mathrm{e}$ & 15.5 \\
Cupravit & $60.1 \mathrm{bc}$ & 19.3 & $18.7 \mathrm{bc}$ & $1.56 \mathrm{~cd}$ & $0.73 \mathrm{~cd}$ & $608.3 \mathrm{c}$ & 25.9 \\
Tilt 250 EC & $54.6 \mathrm{~cd}$ & 26.7 & $20.0 \mathrm{ab}$ & $1.80 \mathrm{~b}$ & $0.85 \mathrm{~b}$ & $700.3 \mathrm{~b}$ & 45.0 \\
Macuprax & $69.8 \mathrm{ab}$ & 6.3 & $17.3 \mathrm{~cd}$ & $1.63 \mathrm{bc}$ & $0.69 \mathrm{~d}$ & $575.0 \mathrm{de}$ & 18.9 \\
Ridomil MZ-72 & $67.8 \mathrm{~b}$ & 8.9 & $17.3 \mathrm{~cd}$ & $1.40 \mathrm{~d}$ & $0.71 \mathrm{~d}$ & $591.6 \mathrm{~cd}$ & 22.4 \\
Control & $74.5 \mathrm{a}$ & & $15.7 \mathrm{~d}$ & $1.37 \mathrm{~d}$ & $0.58 \mathrm{e}$ & $483.3 \mathrm{f}$ & - \\
\hline F-test & $* *$ & & $* *$ & $* *$ & $* *$ & $*$ & $*$ \\
CV (\%) & 6.70 & & 4.79 & 2.51 & 4.89 & 1.46 & \\
\hline
\end{tabular}

Mean (s) in the column followed by common letter (s) do not differ significantly at 0.01 levels. In case of PDI, analysis was done after arcsine transformation.

shown by Rovral 50WP @ 0.2 \% followed by 35.8 and $45.7 \%$ of Dithane M-45. In respect of yield and yield attributes, Rovral 50WP performed the best among the treatments excepting 1000-seed weight where it was statistically similar with Dithane M-45 and Tilt 250EC.

In the present study significant reduction of PDI and increased yield was achieved with fungicidal spray. On the basis of the investigation over the years it is noted that Rovral 50WP@0.2\% was the best fungicide in reducing PDI and increasing yield followed by Dithane M-45 @ 0.2 \% and Tilt 250 EC @ $0.05 \%$. In India, (Gupta and Srivastava, 1988) obtained mancozeb as the best fungicide to control Stemphylium blight of onion bulb crop and gave the highest economic return. In the present study mancozeb gave the second highest yield. Some Indian workers (Gupta, et. al., 1996) attributed effective control measure of purple blotch of onion caused by Stemphylium botryosum with 3 sprays of Rovral 50WP (Iprodione) @ $0.25 \%$. Other Indian workers (Srivastava, et. al., 1995) controlled Stemphylium vesicarium with spraying of Iprodione @ $0.2 \%$. The results of (Bakr and Ahmed, 1992) were in agreement with the findings of the present study.

Successful control of Stemphylium botryosum was achieved by spraying with Rovral 
50WP@0.2\% at an interval of 15 days (Hossain, 2000).

Therefore, Rovral 50WP @ 0.2 \% is recommended as an effective fungicide to control Stemphylium blight of lentil caused by Stemphylium botryosum. Effect of Rovral 50WP in the field is shown below in Plate 1.

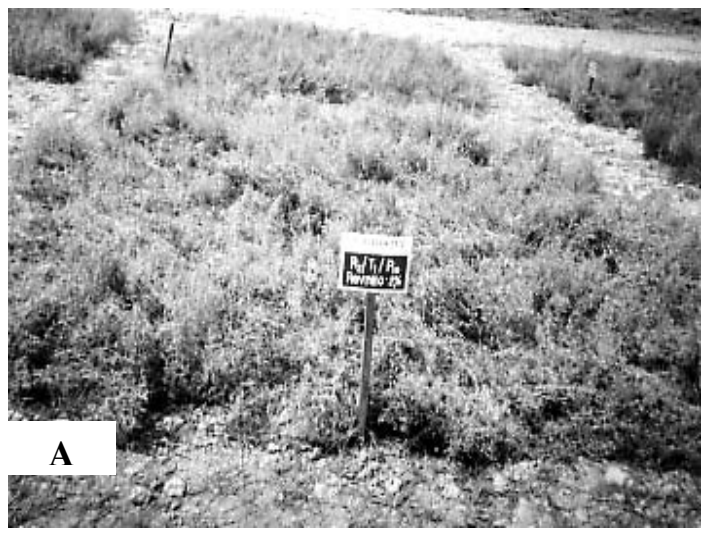

contributed to the highest PDC and corresponding yield followed by Dithane M45 (0.2) and Tilt 250 EC (0.05). PDC was found positively correlated with percent yield increase. It was linear and could be described by equation $\mathrm{y}=1.2959 \mathrm{x}-3.4502$ and regression of coefficient $\mathrm{R}^{2}=0.9132$. (Fig.1).

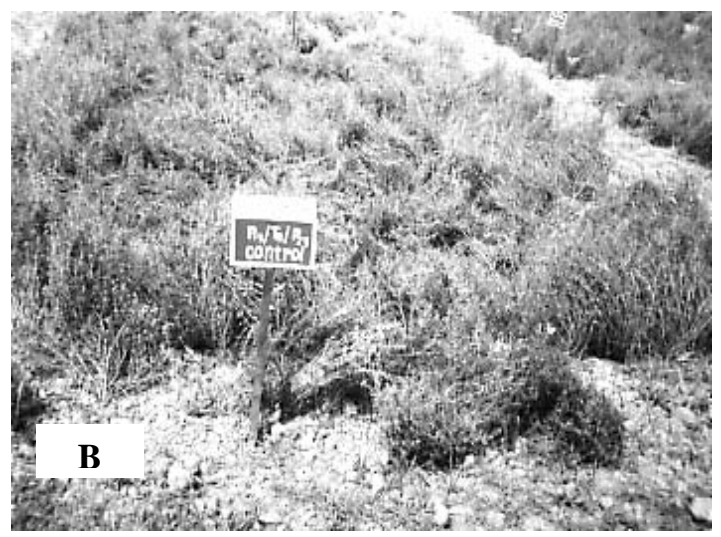

Plate 1. Rovral 50 WP treated and control (untreated) plot of lentil at maturity
A. Treated plot
B. Control (untreated) plot

Relationship between PDC and yield increase over the control during 1998-2001

During 1998-1999 the effect of the fungicides exhibited that Rovral 50WP (0.2)
In 1999-2000 the highest PDC and corresponding yield was given by Rovral 50WP (0.2) followed by Dithane M-45 (0.2) and Tilt 250EC (0.05). The percent yield increase showed positive correlation with PDC which

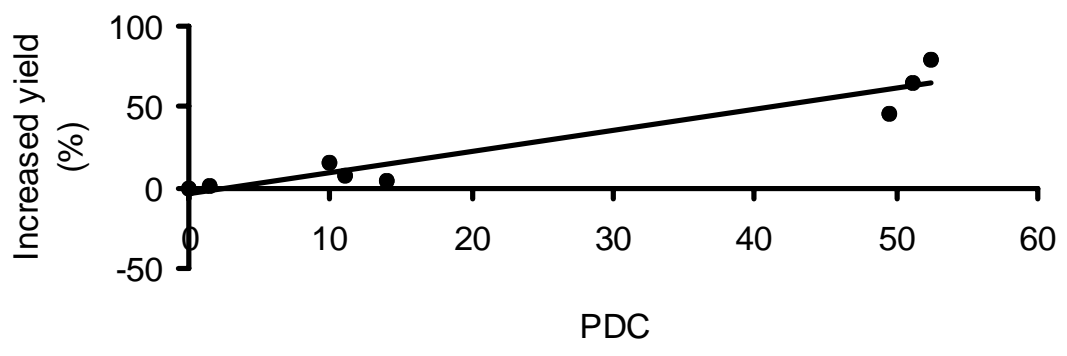

Fig. 1. Relationship between PDC and yield increase over control during 1998-1999 
was linear and exhibited by the equation $y=$ $1.0046 \mathrm{x}+4.1346$ and regression of coefficient $\mathrm{R}^{2}=0.9456$ (Fig. 2 ).
Control through chemical means showed Rovral 50WP@0.2\% as the most effective fungicide when tested in-vivo. Thus, it is rec

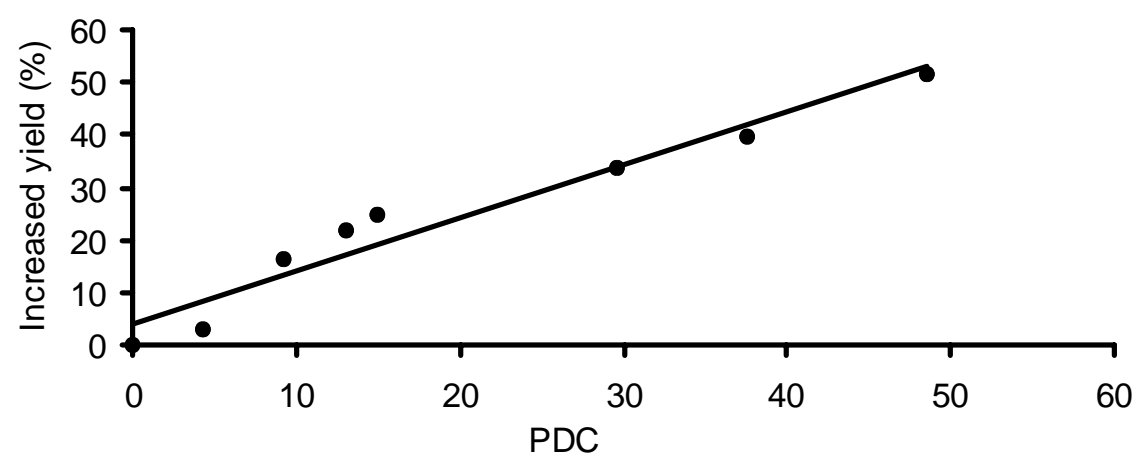

Fig. 2. Relationship between PDC and yield increase over control during 1999-2000

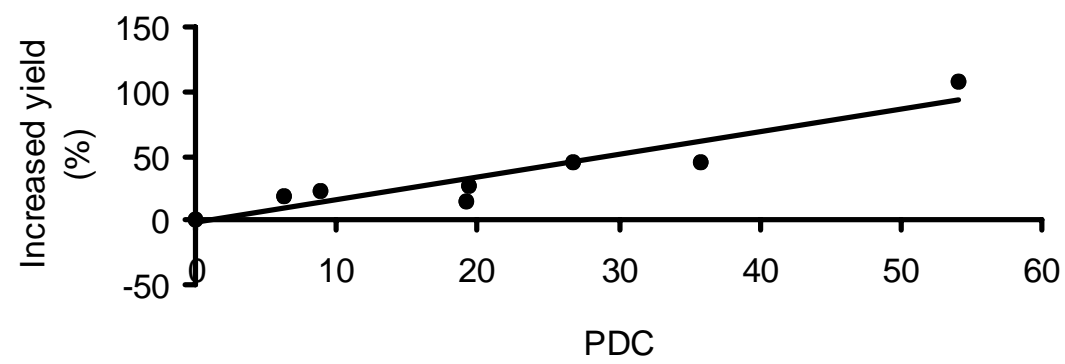

Fig. 3. Relationship between PDC and yield increased over control during 2000-2001

Similarly, in 2000-2001 the highest yield increase with corresponding PDC was recorded from Rovral 50WP (0.2) followed by Dithane M-45 (0.2) and Tilt 250EC (0.05). The yield obtained was correlated positively with PDC which was linear and could be shown by the equation the equation $\mathrm{y}=$ $1.7522 x-2.1533$ and coefficient of regression $\mathrm{R}^{2}=0.8755$. (Fig3). ommended to spray the fungicides thrice at an interval of 15 days from the day of first appreance of disease in the field. However, the control through chemical means is very effective against any disease for which it is still well adapted everywhere in the world. 


\section{References}

Ahmed, H.U. (1985) Disease problems of pules and oilseed crops in Bangladesh. Paper presented in the first National Plant Pathology Conference of Bangladesh Phytopathological Society held at BARI, Joydebpur, Gazipur. pp.13-14.

Anonymous. (1991) Statistical Year Book of Bangladesh. Bangladesh Bureau of Stat. pp. 186.

Bakr M.A. and Zahid, I. (1986) Stemphy-lium blights a new foliar disease of lentil in Bangladesh. Bangladesh J. of Plant Pathol. 2(1) : $69-70$.

Bakr, M.A. and Ahmed, F. (1992) Develop-ment of Stemphylium blight of lentil and it's control. Bangladesh J. of Plant Pathol. 8 (1\&2) : 39-40.

Chowdhury, A.M. and Asheque, A. Sporula-tion of Stemphylium botryosum (Pleospora. herbarum). J. Mycological. Res. 34 (1) : (1996) 69-71.

Gour R.B. and Singh, R.D. Cropping system in relation to chick blight (Ascochyta rabiei) 11, Effect of multirow of intercropping on Ascochyta blight spread. Indian J. Mycol. Pl. Pathol. 20(1) : (1996) 13-15.

Gupta, R.P. Srivastava, P.K. and Sharma, R.C. (1996) Effect of foliar spray of different fungicides on the control of Stemphy-lium blight disease and yield of onion bulb. NHRDF. News Letter 16(1) : 13-15.

Gupta, R.P. and Srivastava, P.K. (1988) Control of Stemphylium blight of onion bulb crop. Indian Phytopathology. 41(3) : 495-496.
Hedge, V.M and Anahosur, K.H. (1994) Influence of sowing dates of mustard on the epidemiology of white rust. Indian Phytopath. 47(4) : 391-394.

Hossain, M.M. 2000. An integrated approach for the control of purple blotch of onion seed crop. Ph. D. thesis. Department of Botany, Rajshahi University, Rajshahi, Bangladesh. pp.170.

Shivankar, S.K. and Wangikar, P. D. (1993) Effect of different fungicides on the control of gray mildew disease of cotton. Indian Phytopath. 46(3): 230-235.

Srivastava, P.K. Sharma, R.C. and Gupta, R. P. (1995) Effect of different fungicides on the control of purple blotch and Stemphy-lium blight disease in onion seed crop. National Horticultural Research Foundation NASIK422001. pp. 6-9.

Steele, R.G.D. and Torrie, J.D. (1980) Principles and procedures of statistics. McGrow-Hill Book Co., New York. pp. 461.

Wheeler, B.E.J. (1969) An Introduction to Plant Diseases. John Wiley and Sons. Ltd. London. pp. 301.

Zaman, S.M.H. Rahim, K. and Howladar, M. (1982) Simple lesson from biometry. Bangladesh Rice Research Institute; Joydebpur, Dhaka, Bangladesh. pp.171.

Received : December 12, 2006;

Accepted : March 14, 2007 